\title{
Metabolik sendrom ile ilișkili erektil disfonksiyonun medikal tedavisi
}

\author{
Treatment of erectile dysfunction related to metabolic syndrome
}

Ali Atan (1)

\section{öz}

Metabolik sendrom diyabetes mellitus, hipertansiyon, obezite ve dislipedimiye bağlı meydana gelen önemli halk sağlığı sorunlarından birisidir. Genelde kardiyovasküler sağlık açısından dikkate alınması gereken bir durum olarak algılanmasına karşın ürolojik hastalıklar açısından da dikkate alınması gereken bir sorundur. Metabolik sendrom varlı̆̆ında en sık görülen ürolojik rahatsılıklardan birisi erektil disfonksiyondur. Metabolik sendromlu kișilerdeki erektil disfonksiyon tedavisinde ilk olarak yaşam tarzının düzeltilmesi ve diyabet, dislipidemi ve hipertansiyon gibi eşlik eden diğer patolojilerin düzeltilmesi gereklidir. Bunlara ek olarak, testosteron replasman tedavisi, aromataz inhibitörleri ve PDE5i'lerinin kullanımı mümkündür. Bu seçeneklerin beklenen faydayı sağlamadığı kişilerde cerrahi tedavi olarak penil protez implantasyonu da uygulanabilmektedir.

Anahtar Kelimeler: Metabolik sendrom, erektil disfonksiyon, tedavi

\section{ABSTRACT}

Metabolic syndrome is one of the major public health problems which happens due to diabetes mellitus, hypertension, obesity and dyslipidemia. Although it is perceived as a condition that should be taken into consideration in terms of cardiovascular health in general, it is a problem that should be taken into account in terms of urological diseases. One of the most common urological disorders in the presence of metabolic syndrome is erectile dysfunction. In the treatment of erectile dysfunction in people with metabolic syndrome, it is first necessary to correct lifestyle and other accompanying pathologies such as diabetes, dyslipidemia and hypertension. In addition, it is possible to use testosterone replacement therapy, aromatase inhibitors and PDE-5i. Penile prosthesis implantation can also be applied as a surgical treatment in those who do not have the expected benefit of these options.

Keywords: Metabolic syndrome, erectile dysfunction, treatment
$\mathbf{M}$ etabolik sendrom (MS); diyabetes mellitus, hipertansiyon, obezite ve dislipidemi gibi sistemik bozuklukların birbirine eklendiği 21. yüzyılın önemli halk sağlığı sorunlarından birisidir. Batı tipi yaşam tarzı olan ülkelerde daha sıktır. Amerika Birleşik Devletleri'nde erişkin popülasyonun \%34-39'unda MS olduğu belirtilmektedir. Çalışmalarda bu tablonun kadın ve erkeklerde eşit oranda görüldüğü de bildirilmektedir. ${ }^{[1]}$

Genelde kardiyovasküler sağlık açısından dikkate alınması gereken bir durum olarak algılanmasına karşın ürolojik hastalıklar açısından da göz önünde bulundurulması gereklidir. Çünkü, MS’le ilişkili olarak; erektil disfonksiyon (ED), infertilite, taş hastalı̆̆ı, benign prostat hiperplazisi,

Gazi Üniversitesi, Tıp Fakültesi, Üroloji Anabilim Dalı, Ankara

Yazışma Adresi / Correspondence:

Prof. Dr. Ali Atan

Birlik Mahallesi, 396 Sokak, 14/11 Çankaya, Ankara - Türkiye

Tel. $\quad+905324242082$

E-mail: aliatanpitt@hotmail.com

Geliş / Received: $\quad$ 10.07.2017

Kabul / Accepted: 10.10 .2017 prostat kanseri, aşırı aktif mesane ve kadınlarda üriner inkontinans artışı da olmaktadır. ${ }^{[2,3]} \mathrm{Bu}$ derlemede, MS ile ilişkili ED'nin tedavisinden bahsedilecektir.

MS ile ilişkili ED, pek çok faktöre bağlı meydana gelmektedir. Bu nedenler; enflamatuvar cevap artışı (periferik arter hastalığı, nitrik oksid sentaz azlığ $)^{[4]}$, adrenerjik akitivitenin $\operatorname{artmasi}^{[5]}$, Rho kinaz aktivitesinin $\operatorname{artmasi}^{[6]}$, hiperglisemi ${ }^{[2,7-9]}$, hipogonadizm ${ }^{[10-15]}$ ve nörojenik faktörlerdir (duyusal nöropati, nörojenik nitrik oksid sentaz azalması). ${ }^{[16,17]}$ Tüm bu nedenler sonucu; vasküler, hormonal ve nörojenik ED görülebilir. Bunlara ek olarak, psikojenik nedenlere bağlı olarak da ED oluşabilmektedir (Şekil 1).

MS ile ilişkili ED tedavisinde ilk yapılması gereken şey yaşam tarzının düzeltilmesidir. Bu anlamda; egzersiz, kilo verme, diyetin düzenlenmesi, aşırı alkol alımının önlenmesi ve sigaranın bırakılması zorunludur. Egzersiz olarak günde 30 dakika veya haftada 150 dakika orta dereceli aerobik aktivite, başlangıçtaki vücut ağırlığının \%5-10'unun verilmesi, diyette sebze, meyve, tahıl ve bakliyat tüketiminin arttırılması, kırmızı et ve hazır gıdaların azaltılması, günlük kalorinin \%10’undan azının doymuş (satüre) yağlardan 


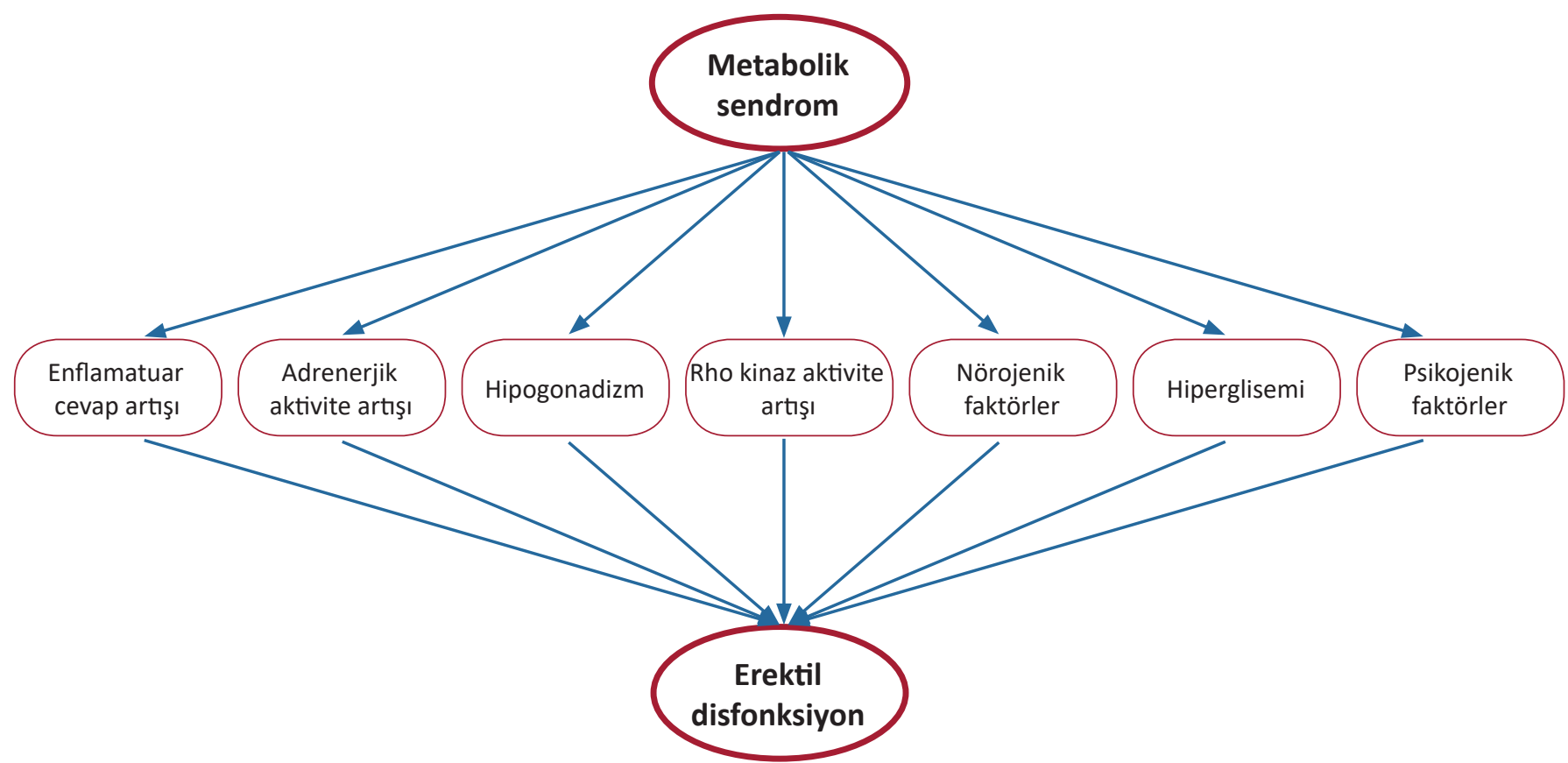

Şekil 1. Metabolik sendromlu kişilerde meydana gelen erektil disfonksiyonun fizyopatolojisi.

elde edilmesi, monosatüre ve polisatüre olmayan yağ asitlerinin alımının arttırılması, şeker katkılı içeceklerden uzak durulması, sigaranın bırakılması ve alkol alımının günde en fazla 1-2 kadeh olacak düzeyde tutulması, tedavinin ilk aşaması olarak önerilmektedir. ${ }^{[18]}$ Avrupa Üroloji Kılavuzu'nda da bu öneriler desteklenmektedir. ${ }^{[19]}$

Bunlara ek olarak, dislipideminin statinler ile düzeltilmesi, oral antidiyabetikler (Metformin) veya insülin ile DM'nin regülasyonu ve hipertansiyonun önlenmesi gereklidir. Hipertansiyonun tedavisi için, 3. kuşak bir beta bloker olan Nebivolol[ ${ }^{[20]}$ veya anjiotensin-II reseptör antagonistleri kullanılabilir. $^{[21]}$

Yaşam tarzının düzeltilmesi ve eşlik eden diğer patolojilerin düzeltilmesi ile beraber bazı medikal tedavilerde MS ile ilişkili ED tedavisinde kullanılabilmektedir. Medikal tedavi olarak, hipogonadizm bulguları olan kişilerde testosteron replasman tedavisi (TRT), aromataz inhibitörleri ve PDE-5i'lerinin kullanımı mümkündür (Tablo 1). Bu seçeneklerin beklenen faydayı sağlamadığı kişilerde cerrahi tedavi olarak penil protez implantasyonu da uygulanabilir. Bu makalede cerrahi tedaviden bahsedilmeyecektir.

MS'li kişilerde, çeşitli mekanizmalarla hipogonadizm geliştiği iyi bilinmektedir. Bu nedenle bu kişilerdeki ED tedavisinde TRT kullanılması ile ilgili pek çok çalışma yapilmıştır. Bu çalışmalarda, testosteron tedavisi ile visseral obezitenin ve insülin direncinin azaldığı, lipid panelinin ve enflamatuvar cevabın düzeldiği gösterilmiştir. ${ }^{[13,22-28]}$ TRT ile MS komponentlerinin düzeldiği gösterilmesine
Tablo 1. Metabolik sendromlu kişilerdeki erektil disfonksiyon medikal tedavisi

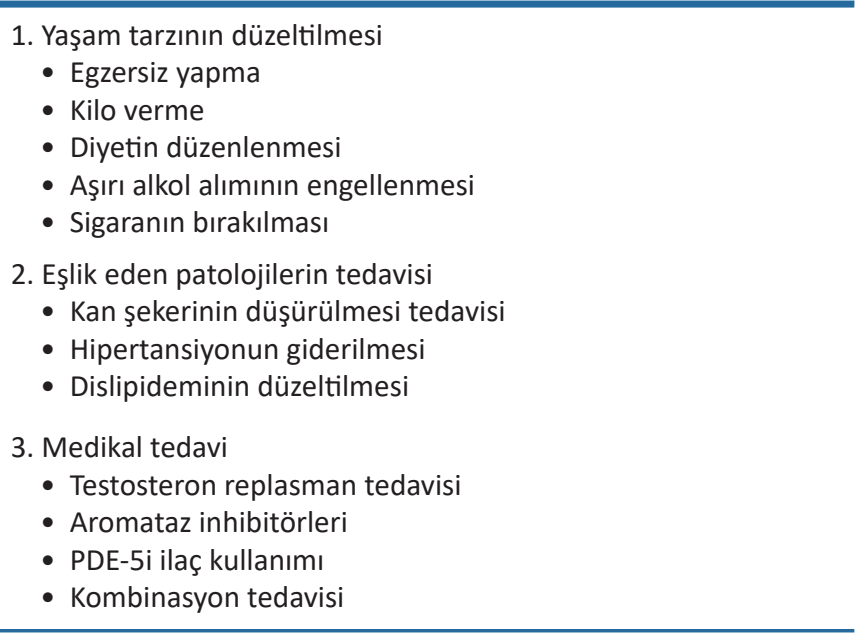

karşın testosteron tedavisinin hangi yöntemle, hangi dozda ve ne sıklıkta verileceği konularında bir kesinlik yoktur. ${ }^{[27]}$ Ayrıca, testosteron tedavisine bağlı olarak kardiyovasküler sağlıkta bir risk artışı olup olmadığı konusu da henüz tartışmalıdır. ${ }^{[28]}$ Testosteron tedavisi; oral tabletler, bukkal tabletler, intramusküler enjeksiyonlar, cilt altı implantlar, transdermal formlar ve intranazal jel şeklinde yapılabilmektedir. ${ }^{[29-31]}$

Ağızdan kullanım için en uygun form, testosteron undekanoattır. Doz ayarlaması yapılabilmektedir. Günlük toplam doz 120-240 mg'dır ve belirlenen miktar günde 2-3 seferde alınabilmektedir. Yemeklerle alımı daha uygundur. Ancak, serum testosteron düzeyi ve etkinlik değişkenlik 
gösterebilmektedir. Bukkal form, günde iki defa $30 \mathrm{mg}$ olarak kullanılmakta ve serum testosteron düzeyi normal sınırlarda kalmaktadır. Mukozada irritasyon, sık kullanım gerekliliği ve tadının acılığı bu formun olumsuz taraflarıdır. İntramusküler olarak verilen testosteron preparatlarının kısa ve uzun etkili formları vardır. Testosteron enantat, testosteron spionat ve testosteron propionat, her 2-3 haftada bir uygulanması gereken formlardır. Bu uygulama şekli ile serum testosteron düzeyi belirgin dalgalanmalar göstermektedir. Enjeksiyondan hemen sonra suprafizyolojik düzeylere çıan serum testosteron düzeyi, 2. haftanın sonunda hipogonadizm düzeylerine inmektedir. Bu dalgalanmalar, kişilerin ruh halinde de değişime yol açabilmektedir. Maliyet açısından avantajlı olmasına karşın serum testosteron düzeyindeki bu değişkenlik ve sık enjeksiyon gerekliliği gibi olumsuz yanları nedeniyle kullanımları sınırlıdır. Uzun etkili testosteron formu ise, hint yağı içinde bulunan testosteron undekanoattır. Her 10-14 haftada bir, $1000 \mathrm{mg}$ şeklinde uygulanır. Bu uygulama şekli ile serum testosteron düzeyleri normal sınırlarda kalır, etkinliği uzun sürer ve bu nedenle enjeksiyonlar genelde üç aylık aralarla yapılır. Testosteronun bu formu ile ilgili sorunlar vardır. Bunlardan biri, enjeksiyonların ağrılı olması ve etkinliğin bitirilmesi gerektiğinde üç aylık bir bekleme süresinin olmasıdır. Cilt altı testosteron implantları ise, özel bir aparat ile cilt altına yerleştirilmektedir. Bir seferde her biri $200 \mathrm{mg}$ testosteron içeren 4-6 implant cilt altına yerleştirilmektedir. Etkinliği yaklaşık altı ay sürmektedir. Girişimsel bir işlem olması, implantların dışarı çıkması ve enjeksiyon alanında enfeksiyon gelişimi gibi komplikasyonları bulunmaktadır. Transdermal testosteron formları; yama, jel ve koltuk altı solüsyonu şeklinde kullanılabilmektedir. Yamalar, günde 5-10 mg testosteron salgılamaktadır. Vücudun biyolojik saati olan "sirkadiyan ritmi" taklit ettiğinden dolayı kullanımları kolaydır. Ancak, ciltte irritasyon yapmaları ve sık kullanım gerekliliği, olumsuz taraflarıdır. Testosteronun jel formu, \%1-2 oranında testosteron içermektedir ve günlük doz 40-80 mg arasındadır. Jel formu da serum testosteron düzeyini normal sınırlarda tutar, daha az cilt irritasyonu yapar ve doz esnekliği sağlar. Temas ile çevreye testosteron aktarılmasına yol açabilmesi ve günlük kullanım gerekliliği olumsuz yanlarıdır. Koltuk altı solüsyon formu, \%2'lik testosteron içermektedir ve günlük düz 60-120 mg'dır. Serum testosteron düzeyini normal sınırlarda tutan testosteronun bu formunun da temasla çevreye testosteron aktarım riski vardır ve günlük kullanım gereklidir. ${ }^{[29,30]}$ Son olarak, 2014 yılı Mayıs ayında FDA onayı almış olan en yeni testosteron ürünü, nasal jel formudur. Önerilen doz, her bir burun deliğinden bir defa burun içerisine uygulanarak verilir. Buruna her sıkılması ile 5,5 mg testosteron verilmektedir. Günde üç defa uygulanır ve bir günde toplam $33 \mathrm{mg}$ testosteron verilir. Nazal mukozadan emilim ile testosteronun karaciğerden geçiş etkisinden kurtulunarak, 40 dakika içerisinde maksimum serum düzeyi elde edilir. Serum testosteron düzeyi fizyolojik sınırlar içerisinde kalır. İlacın bu formunu bırakma oranı \%3,7 olarak bulunmuştur. Girişimsel olmayan ve çevreye transfer riski taşımayan bir kullanım şeklidir. ${ }^{[31]}$

MS ile ilişkili ED tedavisindeki diğer bir seçenek de aromataz inhibitörleridir. Visseral yağ doku artışı ile periferde aromataz aktivitesi artar ve buna bağlı olarak testosterondan östradiol oluşumu fazlalaşır. Östradiol artışı da hipogonadizme neden olur. ${ }^{[32,33]}$ Özellikle obezitesi ön planda olan kişilerde yapılan klinik çalışmalarda, aromataz inhibitörlerinin serum testosteron düzeyini arttırdığı gösterilmiştir. ${ }^{[14,34,35]}$

Fosfodiesteraz Tip-5 inhibitörleri de bu grup hastalarda kullanılabilecek bir diğer tedavi seçeneğidir. Bu grup ilaçlar, ihtiyaç anında veya günlük kullanım şeklinde verilebilir. ${ }^{[8]} \mathrm{Bu}$ konu ile ilgili ilk randomize, plasebo kontrollü, prospektif bir çalışmada, $145 \mathrm{MS}$ 'li ED hastası incelenmiştir. Hastalara 12 hafta vardenafil tedavisi verilmiştir. Bu tedavi sonrası, Vardenafil'in faydalı olduğu gösterilmiştir. ${ }^{[36]}$ Yeni yayımlanmış REVITALISE çalışması ise, toplam 10 ülke ve 171 merkezin katıldığı uluslararası, çok merkezli, prospektif, tek kollu bir gözlem çalışmasıdır. Bu çalışmada, MS ve ED hastalarında Vardenafil'in hem erektil fonksiyon hem hayat kalitesi üzerinde faydalı olduğu bulunmuştur. ${ }^{[37]}$ Tadalafil'de MS'li hastalardaki ED tedavisinde günlük kullanım şeklinde verilmiştir. ${ }^{[38,39]}$ Her iki çalışmada da günlük $5 \mathrm{mg}$ Tadalafil, ED tedavisinde faydalı olmuştur. Mareska ve arkadaşlarının çalışmasında, Tadalafil ile beraber egzersiz yapılmasının etkinliği daha da arttırdığı gösterilmiştir. ${ }^{[38]}$ Özcan ve arkadaşlarının çalışmasında da, Tadalafil tedavisinin erektil fonksiyonu düzeltmekle beraber serum testosteron düzeyini de arttırdığı saptanmıştır. ${ }^{[39]}$ PDE-5i ilaçların serum testosteron düzeyini nasıl arttırdığı ile ilgili deneysel ve klinik çalışmalar vardır. Scipioni ve arkadaşlarının çalışmasında, rat Leydig hücrelerinde bol miktarda PDE-5 ekspresyonunun olduğu ve Sildenafil'in Leydig hücrelerinde steroidogenez üzerinde etkili olduğu gösterilmiştir. ${ }^{[40]}$ Klinik çalsşmalarda da PDE5i ilaçların Leydig hücreleri üzerine etki yaparak testosteron düzeyini arttırdığı saptanmıştır. ${ }^{[1,42]}$

Testosteron ve PDE-5i ilaçların monoterapilerinin yetersiz olduğu olgularda, bu ilaçların birlikte kullanımları da mümkündür. Çeşitli çalışmalarda, önceden verilen PDE-5i tedavisinin başarısız olduğu hipogonadal ve/veya diyabeti olan erkeklerde testosteron tedavisi eklendiğinde etkinliğin arttığı bulunmuştur. ${ }^{[43-46]}$ Bunun tersi olarak, TRT sonrası 
yeterli erektil cevabın elde edilemediği kişilerde de PDE-5i

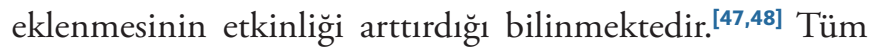
bunlara ek olarak, lipid panelinde bozukluk olan kişilerde PDE-5i ilaçların statinler ile beraber kullanımlarının da etkinliği arttırdığı gösterilmiştir. ${ }^{[49]} \mathrm{Bu}$ etkinlik artışının, statinlerin ve PDE-5i kombinasyonunun erektil dokunun relaksasyon cevabını arttırmasıyla ilişkili olduğu, deneysel bir çalışmada gösterilmiştir. ${ }^{[50]}$

\section{SONUC}

Sonuç olarak, MS ile ilişkili ED, organik ve psikojenik nedenlere bağlı olarak meydana gelebilmektedir. Bu nedenle, bu erkeklerin tedavisi multidisipliner bir yaklaşımı gerektirmektedir. Psikojenik ED için psikolojik destek ve psikiyatrik tedavi öncelikli iken, organik ED varlığında ürologlar ile beraber endokrinoloji, kardiyoloji ve diyet uzmanlarının katkısı gereklidir. Yaşam tarzının düzeltilmesi, diyabetin, hipertansiyonun ve dislipideminin tedavisi ile beraber, TRT, aromataz inhibitörleri ve PDE-5i ilaçlar bu hastalarda kullanılabilmektedir.

\section{Hakem Değerlendirmesi}

Dış bağımsız

\section{Çıkar Çatışması}

Yazar çıkar ilişkisi olmadığını beyan etmiştir.

\section{Peer-review}

Externally peer-reviewed.

Conflict of Interest

No conflict of interest was declared by the author.

\section{KAYNAKLAR}

1. Golden SH, Robinson KA, Saldanha I, Anton B, Ladenson PW. Clinical review: Prevalence and incidence of endocrine and metabolic disorders in the United States: a comprehensive review. J Clin Endocrinol Metab 2009;94:1853-78. doi: 10.1210/jc.2008-2291

2. Gorbachinsky I, Akpinar H, Assimos DG. Metabolic syndrome and urologic diseases. Rev Urol 2010;12:157-80.

3. Hammarsten J and Peeker R. Urological aspects of the metabolic syndrome. Nat Rev Urol 2011;8:483-94. doi: 10.1038/ nrurol.2011.112

4. Traish AM, Feeley RJ, Guay A. Mechanisms of obesity and related pathologies: androgen deficiency and endothelial dysfunction may be the link between obesity and erectile dysfunction. FEBS J 2009;276:5755-67. doi: 10.1111/j.1742-4658.2009.07305.x

5. Brotman DJ and Girod JP. The metabolic syndrome: a tug-of-war with no winner. Cleve Clin J Med 2002;69:990-4.

6. Wingard C, Fulton D, Husain S. Altered penile vascular reactivity and erection in the Zucker obese-diabetic rat. J Sex Med 2007;4:348-62. doi: 10.1111/j.1743-6109.2007.00439.x

7. McVary K. Lower urinary tract symptoms and sexual dysfunction: epidemiology and pathophysiology. BJU Int 2006;97:23-8. doi: 10.1111/j.1464-410X.2006.06102.x

8. Fonseca V, Jawa A. Endothelial and erectile dysfunction, diabetes mellitus, and the metabolic syndrome: common pathways and treatments? Am J Cardiol 2005;96:13M-18M. doi: 10.1016/j. amjcard.2005.07.005
9. Lee RK, Chughtai B, Te AE, Kaplan SA. Sexual function in men with metabolic syndrome. Urol Clin North Am 2012;39:53-62. doi: 10.1016/j.ucl.2011.09.008

10. Chrousos GP. Stressors, stress, and neuroendocrine integration of the adaptive response. The 1997 Hans Selye Memorial Lecture. Ann N Y Acad Sci 1998;851:311-35.

11. Castro-Fernandez C, Olivares A, Söderlund D, López-Alvarenga JC, Zambrano E, Veldhuis JD, et al. A preponderance of circulating basic isoforms is associated with decreased plasma half-life and biological to immunological ratio of gonadotropin-releasing hormone-releasable luteinizing hormone in obese men. J Clin Endocrinol Metab 2000;85:4603-10. doi: 10.1210/jc.85.12.4603

12. Rosmond R, Wallerius S, Wanger P, Martin L, Holm G, Björntorp P. A 5-year follow-up study of disease incidence in men with an abnormal hormone pattern. J Intern Med 2003;254:386-90.

13. Kalyani RR and Dobs AS. Androgen deficiency, diabetes, and the metabolic syndrome in men. Curr Opin Endocrinol Diabetes Obes 2007;14:226-34. doi: 10.1097/MED.0b013e32814db856

14. Loves S, Ruinemans-Koerts J, de Boer H. Letrozole once a week normalizes serum testosterone in obesity-related male hypogonadism. Eur J Endocrinol 2008;51:741-7. doi: 10.1530/EJE-07-0663

15. Cohen PG. Obesity in men: the hypogonadal-estrogen receptor relationship and its effect on glucose homeostasis. Med Hypotheses 2008;70:358-60. doi: 10.1016/j.mehy.2007.05.020

16. Saenz de Tejada I, Goldstein I. Diabetic penile neuropathy. Urol Clin North Am 1998;15:17-22.

17. Nehra A, Moreland RB. Neurologic erectile dysfunction. Urol Clin North Am 2001;28:289-308.

18. Maiorino MI, Bellastella G, Esposito K. Lifestyle modifications and erectile dysfunction: what can be expected? Asian J Androl 2015;17:5-10. doi: 10.4103/1008-682X.137687

19. Hatzimouratidis K, Giuliano F, Moncada I, Muneer A, Salonia A, Verze P. EAU Guidelines on erectile dysfunction, premature ejaculation, penile curvature and priapism, EAU Male Sexual Dysfunction-Limited Update, March 2017.

20. Cordero A, Bertomeu-Martínez V, Mazón P, Fácila L, BertomeuGonzález V, Conthe P, et al. Erectile dysfunction in high-risk hypertensive patients treated with beta-blockade agents. Cardiovasc Ther 2010;28:15-22. doi: 10.1111/j.1755-5922.2009.00123.x

21. Dusing R. Effect of the angiotensin II antagonist valsartan on sexual function in hypertensive men. Blood Press Suppl 2003;2:29-34.

22. Traish AM, Guay A, Feeley R, Saad F. The dark side of testosterone deficiency: I. Metabolic syndrome and erectile dysfunction. J Androl 2009;30:10-22. doi: 10.2164/jandrol.108.005215

23. Corona G, Rastrelli G, Monami M, Saad F, Luconi M, Lucchese M, et al. Body weight loss reverts obesity-associated hypogonadotropic hypogonadism: a systematic review and meta-analysis. Eur J Endocrinol 2013;168:829-43. doi: 10.1530/EJE-12-0955

24. Saad F, Haider A, Doros G, Traish A. Long-term treatment of hypogonadal men with testosterone produces substantial and sustained weight loss. Obesity (Silver Spring) 2013;21:1975-81. doi: 10.1002/oby. 20407

25. Yassin DJ, Doros G, Hammerer PG, Yassin AA. Long-term testosterone treatment in elderly men with hypogonadism and erectile dysfunction reduces obesity parameters and improves metabolic syndrome and health-related quality of life. J Sex Med 2014;11:1567-76. doi: 10.1111/jsm.12523

26. Musicki B, Bella AJ, Bivalacqua TJ, Davies KP, DiSanto ME, Gonzalez-Cadavid NF, et al. Basic science evidence for the link between erectile dysfunction and cardiometabolic dysfunction. J Sex Med 2015;12:2233-55. doi: 10.1111/jsm.13069 
27. Kovac JR, Pastuszak AW, Lamb DJ, Lipshultz LI. Testosterone supplementation therapy in the treatment of patients with metabolic syndrome. Postgrad Med 2014;126:149-56. doi: 10.3810/pgm.2014.11.2843

28. Taylor SR, Meadowcraft LM, Williamson B. Prevalence, Pathophysiology, and Management of Androgen Deficiency in Men with Metabolic Syndrome, Type 2 Diabetes Mellitus, or Both. Pharmacotherapy 2015;35:780-92. doi: 10.1002/phar.1623

29. Corona G, Vignozzi L, Sforza A, Maggi M. Risks and benefits of late onset hypogonadism treatment: an expert opinion. World J Mens Health 2013;31:103-25. doi: 10.5534/wjmh.2013.31.2.103

30. Isidori AM, Buvat J, Corona G, Goldstein I, Jannini EA, Lenzi A, et al. A critical analysis of the role of testosterone in erectile function: from pathophysiology to treatment-a systematic review. Eur Urol 2014;65:99-112. doi: 10.1016/j.eururo.2013.08.048

31. Shoskes JJ, Wilson MK, Spinner ML. Pharmacology of testosterone replacement therapy preparations. Transl Androl Urol 2016;5:834-43. doi: 10.21037/tau.2016.07.10

32. Foresta C, Caretta N, Aversa A, Bettocchi C, Corona G, Mariani S, Rossato M. Erectile dysfunction: symptom or disease? J Endocrinol 2004;27:80-95. doi: 10.1007/BF03350917

33. Foresta C, Caretta N, Corona G, Fabbri A, Francavilla S, Jannini E, et al. Clinical and metabolic evaluation of subjects with erectile dysfunction: a review with a proposal flowchart. Int J Androl 2009;32:198-211. doi: 10.1111/j.1365-2605.2008.00932.x

34. de Boer H, Verschoor L, Ruinemans-Koerts J, Jansen M. Letrozole normalizes serum testosterone in severely obese men with hypogonadotropic hypogonadism. Diabetes Obes Metab 2005;7:211-5. doi: 10.1111/j.1463-1326.2004.00397.x

35.Loves S, de Jong J, van Sorge A, Telting D, Tack CJ, Hermus A, et al. Somatic and psychological effects of low-dose aromatase inhibition in men with obesity-related hypogonadotropic hypotestosteronemia. Eur J Endocrinol 2013;169:705-14. doi: 10.1530/EJE-13-0190

36. Schneider T, Gleissner J, Merfort F, Hermanns M, Beneke M, Ulbrich E. Efficacy and safety of vardenafil for the treatment of erectile dysfunction in men with metabolic syndrome: results of a randomized, placebo-controlled trial. J Sex Med 2011;8:2904-11. doi: 10.1111/j.1743-6109.2011.02383.x

37. Shabsigh R, Mattern A, REVITALISE Study Group. REVITALISE: A Large Observational Study Assessing the Safety and Effectiveness of Vardenafil in Men With Erectile Dysfunction and Metabolic Syndrome. J Sex Med 2016;4:e135-44. doi: 10.1016/j.esxm.2016.03.027

38. Maresca L, D’Agostino M, Castaldo L, Vitelli A, Mancini M, Torella G, et al. Exercise training improves erectile dysfunction (ED) in patients with metabolic syndrome on phosphodiesterase-5 (PDE-5) inhibitors. Monaldi Arch Chest Dis 2013;80:177-83.

39. Ozcan L, Polat EC, Kocaaslan R, Onen E, Otunctemur A, Ozbek E. Effects of taking tadalafil $5 \mathrm{mg}$ once daily on erectile function and total testosterone levels in patients with metabolic syndrome. Andrologia 2017. doi: 10.1111/and.12751
40. Scipioni A, Stefanini S, Santone R, Giorgi M. Immunohistochemical localisation of PDE5 in Leydig and myoid cells of prepuberal and adult rat testis. Histochem Cell Biol 2005;124:401-7. doi: 10.1007/s00418-005-0057-1

41. Carosa E, Martini P, Brandetti F, Di Stasi SM, Lombardo F, Lenzi A, et al. Type $V$ phosphodiesterase inhibitor treatments for erectile dysfunction increase testosterone levels. Clin Endocrinol (Oxf) 2004;6:382-6.

42. Spitzer M, Bhasin S, Travison TG, Davda MN, Stroh H, Basaria S. Sildenafil increases serum testosterone levels by a direct action on the testes. Andrology 2013;1:913-8. doi: 10.1111/j.20472927.2013.00131.x

43. Kalinchenko SY, Kozlov GI, Gontcharov NP, Katsiya GV. Oral testosterone undecanoate reverses erectile dysfunction associated with diabetes mellitus in patients failing on sildenafil citrate therapy alone. Aging Male 2003;6:94-9.

44. Shabsigh R, Kaufman JM, Steidle C, Padma-Nathan H. Randomized study of testosterone gel as adjunctive therapy to sildenafil in hypogonadal men with erectile dysfunction who do not respond to sildenafil alone. J Urol 2004;172:658-63. doi: 10.1097/01.ju.0000132389.97804.d7

45. Yassin AA, Saad F, Diede HE. Testosterone and erectile function in hypogonadal men unresponsive to tadalafil: results from an open-label uncontrolled study. Andrologia 2006;38:61-8. doi: 10.1111/j.1439-0272.2006.00712.x

46. Garcia JA, Sanchez PE, Fraile C, Escovar P. Testosterone undecanoate improves erectile dysfunction in hypogonadal men with the metabolic syndrome refractory to treatment with phosphodiesterase type 5 inhibitors alone. Andrologia 2011;43:293-6. doi: 10.1111/j.1439-0272.2009.00991.x

47. Greenstein A, Mabjeesh NJ, Sofer M, Kaver I, Matzkin H, Chen J. Does sildenafil combined with testosterone gel improve erectile dysfunction in hypogonadal men in whom testosterone supplement therapy alone failed? J Urol 2005;173:530-2. doi: 10.1097/01.ju.0000149870.36577.05

48. Rosenthal BD, May NR, Metro MJ, Harkaway RC, Ginsberg PC. Adjunctive use of AndroGel (testosterone gel) with sildenafil to treat erectile dysfunction in men with acquired androgen deficiency syndrome after failure using sildenafil alone. Urology 2006;67:571-4. doi: 10.1016/j.urology.2005.09.032

49. Gokkaya SC, Ozden C, Ozdal L, Koyuncu H, Guzel O, Memis A. Effect of correcting serum cholesterol levels on erectile function in patients with vasculogenic erectile dysfunction. Scand J Urol Nephrol 2008;42:437-40. doi: 10.1080/00365590801950279

50. Erden Y, Korgalı E, Dundar G, Ayan S, Gokce G, Yildirim S, et al. In-vitro effects of PDE5 inhibitor and statin treatment on the contractile responses of experimental MetS rabbit's cavernous smooth muscle. Arc Ital Urol Androl 2014;86:33-8. doi: 10.4081/ aiua.2014.1.33 